\title{
Attitude towards ICT: a statistical analysis of gender differences in Spanish higher education teachers
}

\author{
Francisco D. Guillén-Gámez ${ }^{1}$, Ernesto Colomo-Magaña ${ }^{2}$, Enrique Sánchez-Rivas², Rocío Pérez \\ del Río ${ }^{3}$ \\ ${ }^{1}$ University of Zaragoza (UNIZAR), Department of Research and Diagnostic Methods in Education \\ ${ }^{2}$ University of Málaga (UMA), Department of Theory and History of Education, \\ ${ }^{3}$ University of Málaga (UMA), Department of Didactics and School Organization
}

\begin{abstract}
The use of ICT resources in the teaching and learning process, as well as in the field of educational research, requires positive attitudes from all higher education teachers. Therefore, the purposes of this study are: (1) to measure both the level of attitude of teachers towards technology related to the teaching and learning process and the level of attitude towards technology related to research in both genders; and (2) to know if there are differences in the attitudes of teachers according to their gender. For this, an ex post facto design with 867 higher education teachers from the Spanish territory was used. An instrument created by RomeroMartínez et al. (2020) was composed of a total of 18 items, classified into three dimensions: affective, cognitive and behavioural attitudes towards technology in the teaching and learning process; affective attitudes towards technology in educational research; and cognitive attitudes towards technology in educational research. In general, the results showed that the teachers perceived a very good attitude towards technology (3.9/5), being higher in the male gender. Specifically, significant differences were found between both genders in the global attitude towards technology, as well as in the affective attitudes dimension towards ICT research. The conclusions derived from this study can help to develop training actions focused on improving the most unfavourable attitudes of each gender.
\end{abstract}

Keywords: diagnosis; gender; teachers; measurement; technology

\section{Preface}

In the current context, the technological revolution has given rise to a digitalised society, characterised by continuous changes. This factor is manifested in a constant state of evolution and development that includes different areas of reality, such as education. In this sense, the Information and Communication Technologies (ICT) have become an instrument to transform 


\section{$3^{\text {rd }}$ International conference on Advanced Research in Education, Teaching \& Learning}

the pedagogical and methodological praxis of the formative processes. Despite this, these advances are not always accompanied by educational policies that take advantage of technological equipment or specific training for teachers. Because of this, it is necessary that teachers must be trained and improve their digital pedagogical skills in order to correctly use technologies in their educational work (Guillén-Gámez and Mayorga-Fernández, 2020a; Spiteri and Chang, 2020).

In this sense, despite the transformations in innovation and methodologies that technological revolution has brought about in the field of higher education, studies such as that of Mirete et al. (2020) confirm that teachers who start from a traditional approach to the training process have a negative view of the use of technologies for such work. In contrast to this situation, works such as Pacheco et al. (2015) highlight the positive impact that the implementation of ICT has on student learning. Linked to this, some studies have focused specifically on the academic performance of students, allowing them to measure how the application of ICT affects them (Gómez-García et al., 2020; Guillén-Gámez et al., 2018). In contrast, research that has analysed teachers' attitudes towards ICT at university level continues to be a minority (Arango et al., 2020; Guillén-Gámez and Mayorga-Fernández, 2020b; Mirete et al., 2020).

Nevertheless, this represents a key area of study. The possibilities that are generated in the educational context by the full evolution and continuous development of the technological means, at the level of resources and tools, are exponentially high. Nevertheless, if teachers show reticence or negative attitudes towards them, their integration will be affected. In contrast, a greater predisposition and positive attitude towards their incorporation are related to more effective use of ICT in the educational process (Casillas et al., 2020; Fernández-Batanero and Torres-González, 2015).

Considering the premise stated above, the purpose of this study is to analyse the attitudes towards ICT of university teachers regarding the teaching-learning process and research, specifically considering the gender variable.

\section{Theoretical framework}

\section{Approach to the concept of attitude towards ICT and its structure}

When we talk about attitudes, we are referring to an intangible reality that manifests itself through people's thoughts, acts, beliefs, or words. These are the elements that guide people's behavior and actions, the result of the emotional (feelings) and cognitive (thoughts) analysis they make of reality. Therefore, they come from the world of ideas and are materialised in different areas of the subject's behaviour (dimensions), which makes it difficult to evaluate them all at once (Ankiewicz, 2019). Another conception of attitudes alludes to the subjective response of the individual (with positive or negative polarity) concerning the valuation of some object or belief (Kumar and Ratnakar, 2016). 


\section{$3^{\text {rd }}$ International conference on Advanced Research in Education, Teaching \& Learning}

Referring to the educational field, the attitudes of the teaching staff will influence the decisionmaking of the teaching-learning processes. In this sense, a negative vision or assessment of ICT will become an obstacle or barrier to its inclusion as a teaching strategy or training resource. Because of this, the positive attitude of university teachers is key to incorporating technologies in the training context if we want a technological transformation that allows innovation and methodological change (Arango et al., 2020).

However, when talking about attitudes towards ICT, we do not find a univocal interpretation, but different proposals of categories according to the researchers who have been approaching them. Due to the multifaceted vision from which attitudes towards ICT are worked, the study by Cai et al. (2017) stands out, differentiating between the emotional factor linked to the use of ICT; personal interest and subjective satisfaction when using the technologies; beliefs regarding how ICT influences society and its usefulness; or the perception of effectiveness regarding its positive implementation.

The multiple options regarding the dimensions that can be considered in attitudes have led to a debate among specialists and the proliferation and identification of different categories (Ankiewicz, 2019; Rosen et al., 2016). Among the different proposals, we adhere to the one shaped by the affective, cognitive and behavioural dimensions (Maio et al., 2018). Concerning affective attitudes, they are linked to the emotional factor (feelings and emotions) that influence the actions and reactions of the person, providing them a subjective perception that will condition behaviour and the way they act in the face of the different situations and events that they face (Zhang et al, 2020). On the other hand, cognitive attitudes are generated around the beliefs and values that each person assumes according to the learning that has been acquired during their experiences and that will determine both future actions and the (re)construction of our ideas and thoughts (Elliot and Wilmes, 2013; González-Sanmamed et al., 2017). Finally, behavioural attitudes are linked to the behaviour and intention that is generated in a subject before a certain situation that conditions the way of acting (Ursavas et al., 2015).

\section{Attitudes towards ICT: related studies}

Attitudes towards technology have gained relevance as an area of scientific research in recent years. Evidence of this is provided by the work of Mirete et al. (2020), which measures attitudes, knowledge, and use of ICT and its relationship with the transmission of information and the construction of knowledge; that of Arango et al. (2020), which evaluates the influence of attitudes, training, and level of technological literacy on the incorporation of ICT in higher education; or that of Prasojo et al. (2019) that analyses the attitudes and perceptions of teachers regarding the integration of ICT in schools in rural areas of Indonesia. However, these studies do not specifically address the affective, cognitive, and behavioral dimensions that shape attitudes.

A situation that is considered in the work of Guillén-Gámez and Mayorga-Fernández (2020b) was represented by the three dimensions which obtained an average score by university teachers, where the cognitive one showed the highest score, and the behavioral one, the lowest. Other studies that have considered said dimensions, but having differed regarding the results, have been those of Judi et al. (2016) and Abdullah et al. (2015). In both the affective dimension 


\section{$3^{\text {rd }}$ International conference on Advanced Research in Education, Teaching \& Learning}

showed the lowest score, having a better consideration than cognitive and behavioural dimensions regarding the use and integration of ICT by teachers. In contrast, Wahyuni's (2018) work emphasises that affective attitudes are the ones most related to the use of technologies and the level of digital competence in teachers.

In addition to studies that contemplate these dimensions, scientific production around factors that can promote a positive attitude towards ICT in university teachers has proliferated. Thus, the study by Alvarado et al. (2020) analyses the attitudes towards ICT of 56 Ecuadorian teachers from a qualitative perspective, reflecting that technological endowment and specific training in digital competence are key aspects for a more positive vision of the integration of technologies in educational processes. For its part, the work of Guillén-Gámez and MayorgaFernández (2020a) found significant differences between the attitudes towards ICT of university teachers and graduate students, the latter obtaining a better consideration. Also noteworthy is the research of Olafare et al. (2018) and Semerci and Aydin (2018), where teachers with less work experience had more positive attitudes towards the integration of ICT than teachers with more extensive experience. Finally, linked to our proposal, we highlight the work of Onasanya et al. (2010), who found that gender did not lead to significant differences in the attitudes of 150 university teachers regarding the integration of ICT in the training process.

Despite this, there is still a need for more research on attitudes towards ICT. In this study, we will place the main focus on analysing the influence of affective, cognitive, and behavioural attitudes towards ICT of university teachers concerning the teaching-learning processes and research work, having gender as a study variable. Together with this, we will know if there are significant differences in attitudes according to the gender variable.

\section{Method}

Design and participants. A non-experimental design was used through surveys during the 2018/2019 academic year, to collect university faculties' self-perception of their attitudes towards ICT. The sample was of 867 teachers of higher education from the Spanish educational system. Specifically, $47.9 \%$ were women $(n=415)$ with a mean age of 46.56 years, while $52.1 \%$ of the sample were men with a mean age of 48.47 years.

Instrument. To measure attitudes towards ICT, we used the questionnaire of Attitudes towards Technology for Teaching and Research CAT-EI, elaborated by Romero-Martínez et al. It is composed of a total of 18 items organised into three factors. Factor 1 (ACC-E) is made up of the items developed for measuring the behavioural and affective dimensions related to the use of ICT for teaching, with a total of 9 items. Factor 2 (A-I) refers to the affective dimension, related to the use of technology for research, with a total of 5 items. Finally, factor 3 (C-I) consists of 4 items corresponding to the cognitive dimension, related to the use of ICT for research. Factor 2 was written in the opposite way in the original instrument. For this study, it was translated into positive terms so that the three dimensions would have the same polarity. 


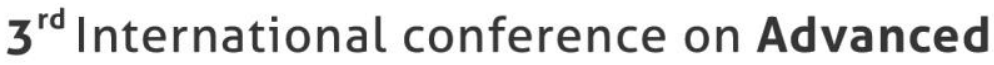 Research in Education, Teaching \& Learning}

The instrument used indicated correct psychometric properties. Regarding the reliability of the instrument, the authors found Cronbach's Alpha coefficients with values ranging from 0.71 to 0.93, which indicated good reliability of the instrument. Table 1 shows the coefficients for each dimension of the instrument, as well as the coefficients for the overall assessment.

Table 1. Instrument reliability (95\% confidence intervals)

\begin{tabular}{lcccc}
\hline Scala & ACC-E & A-I & C-I & CAT-EI \\
\hline Cronbach's Alpha & .929 & .700 & .706 & .872 \\
\hline
\end{tabular}

Regarding the validity of the instrument, confirmatory factor analysis (CFA) was performed to confirm the proposed three-dimensional structure found by exploratory factor analysis (EFTA). The adjustment indexes found showed that the model correctly fits the required values, confirming a three-dimensional structure. Table 2 shows the coefficients found in each CFA statistic.

Table 2. Adjustment index of CFA

\begin{tabular}{lllllllll}
\hline $\mathrm{SB} \chi^{2}$ & $\mathrm{df}$ & $\mathrm{p}$ & $\mathrm{CFI}$ & $\mathrm{TLI}$ & $\mathrm{NFI}$ & GFI & RMSEA & $90 \% \mathrm{CI}$ \\
\hline 302.38 & 116 & $<.001$ & .978 & .974 & .947 & .971 & .040 & {$[.040-.054]$} \\
\hline
\end{tabular}

Procedure. Data collection was carried out through online surveys using Google forms. The questionnaire was sent by email to a total of 12,538 teachers, of which, as indicated above, a total of 867 completed the questionnaire. At the beginning of the questionnaire, the objective of the research was underlined, guaranteeing the privacy of the participants as the surveys are anonymous.

\section{Results}

This part was divided into four sections, one for each dimension of the instrument, as well as one for the overall attitude. Each section contained two types of analysis: first, teacher attitudes were analysed and compared descriptively for each of the items, and then the most appropriate statistic (non-parametric) was used for independent sample comparison (Mann-Whitney).

\section{Affective, cognitive and behavioural attitudes for teaching}

Table 3 shows the attitudes of teachers towards affective, cognitive, and behavioural aspects of teaching with ICT. It can be seen that the most valued item is "I think that ICT is important in the teaching-learning process and should be worked on in a transversal way", both for the female gender $(M=4.27)$ and the male gender $(M=4.28)$, with practically equal values. This level is really good, taking into consideration the five-point Likert scale, and is very much substantiated by other beliefs of teachers such as, for example, "I am attracted to knowing new 


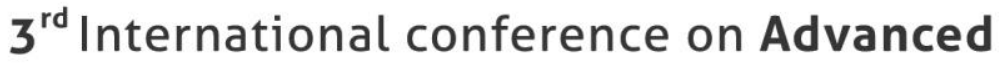 Research in Education, Teaching \& Learning}

ICT tools that I can use in the classroom", with equal averages in both genders $(M=3.94)$, or "ICT is part of my daily life in the classroom", being slightly higher in the female gender (3.85). On the side of the items with less valuation, although with positive attitudes as well, we found the item "ICT plays an important role in planning my teaching", being slightly higher for the male gender $(M=3.29)$. In general, the attitude of the teachers is very positive for both genders, slightly superior for the male gender $(M=3.75)$ with only a couple of tenths of a percent difference with respect to the female gender $(M=3.71)$.

Table 3. Descriptive results of factor 1 comparing by gender

\begin{tabular}{lllll}
\hline Item & \multicolumn{3}{l}{ Female } & \multicolumn{2}{l}{ Male } \\
& $\bar{X}$ & Sd. & $\bar{X}$ & Sd. \\
\hline ICT plays an important role in the planning of my teaching & 3.25 & 1.19 & 3.29 & 1.22 \\
My way of interacting with students is enhanced by my use of ICT with them & 3.81 & 1.14 & 3.87 & 1.14 \\
ICT is part of my daily life in the classroom & 3.85 & 1.24 & 3.75 & 1.23 \\
I like that my methodology is based on the transversal use of ICT & 3.35 & 1.22 & 3.45 & 1.16 \\
In my classes, I encourage my students to use ICT & 3.62 & 1.17 & 3.71 & 1.17 \\
I believe that ICT is helping me to have a more innovative teaching and evaluation & 3.55 & 1.20 & 3.53 & 1.16 \\
methodology & & & & \\
I believe that ICT is important in the teaching-learning process and should be & 4.27 & 0.85 & 4.28 & 0.89 \\
worked on in a transversal way & 3.94 & 1.08 & 3.94 & 1.11 \\
I am attracted to new ICT tools that I can use in the classroom & 3.70 & 1.14 & 3.91 & 1.09 \\
I feel confident when I use ICT in the classroom & 3.71 & 0.90 & 3.75 & 0.91 \\
Total factor 1 & & & &
\end{tabular}

The normality of the data obtained was calculated with the Kolmogorov-Smirnov statistician when working with a large sample. The values obtained in this test on factor 1 were lower than $0.05(\mathrm{KS}=0.081 ; \mathrm{sig} .=0.001)$, so the normality of the data was rejected. Therefore, the MannWhitney test was used, which compares the average ranges of two independent samples. No statistically significant differences were found in the affective, cognitive, and behavioural attitudes towards technology in the field of teaching by teachers, once both genders were compared, therefore, the null hypothesis was accepted $(\mathrm{U}=86117.000 ; \mathrm{Z}=-1.009 ;$ sig. $<0.05)$.

\section{Affective attitudes related to the use of technology for research}

In general, the affective attitudes of teachers regarding technology in the field of research are positive and good (see table 4$)$, being slightly higher in male teachers $(M=3.65)$ compared to female teachers $(M=3.35)$. Specifically, it is observed that the item with the most positive evaluation is "I like using computer programs for data processing when I carry out research", both for the female gender $(M=3.74)$ and the male gender $(M=4.10)$, the latter being slightly higher. On the other hand, the least valued items, with the consequent lower attitude on the part of the faculty, are two: "I like dedicating part of my time to disseminating research activities through social networks", where the female faculty obtains a lower average $(M=2.99)$ compared to the male $(\mathrm{M}=3.25)$; and "I am happy to have to update my academic profile on the Internet", is less valued by the female faculty $(\mathrm{M}=2.80)$ than by the male $(\mathrm{M}=3.08)$. 


\section{$3^{\text {rd }}$ International conference on Advanced Research in Education, Teaching \& Learning}

Table 4. Descriptive results of factor 2 comparing by gender

\begin{tabular}{lllll}
\hline Item & \multicolumn{3}{l}{ Female } & \multicolumn{2}{l}{ Male } \\
& $\bar{X}$ & Sd. & $\bar{X}$ & Sd. \\
\hline I like dedicating part of my time to disseminating research activities through social & 2.99 & 1.31 & 3.25 & 1.40 \\
networks & 2.80 & 1.35 & 3.08 & 1.40 \\
I am happy to have to update my academic profile on the Internet & 3.68 & 1.30 & 3.99 & 1.16 \\
I like to access databases and web browsers & 3.74 & 1.32 & 4.10 & 1.20 \\
I like having to use software for data processing when I do research & 3.54 & 1.32 & 3.80 & 1.28 \\
I like to use an ICT-based methodology for research & 3.35 & 0.91 & 3.65 & 0.84 \\
Total factor 2 & & &
\end{tabular}

In the normality test, the Kolmogorov-Smirnov statistician rejected the assumption of normality $(\mathrm{KS}=0.061$; sig. $=0.001)$. Significant differences were found in affective attitudes towards ICT research between both genders $(U=73163,500 ; Z=-4,791 ;$ sig. $<0.05)$, so the null hypothesis was rejected. The effect size is only calculated if the significance level is less than 0.05 , being calculated with Eta squared $(\eta 2)$, where a value of 0.01 is a small effect size, a value of 0.06 is a medium effect, and a value greater than 0.14 is a large effect. For this factor, the effect size found was between small and medium $(\eta 2=0.03)$.

\section{Cognitive attitudes related to the use of technology for research}

Finally, in table 5 we observe the cognitive attitudes of teachers about technology for research. In general, teachers perceive satisfactory and positive attitudes, being slightly higher in male teachers $(M=4.32)$ than in female teachers $(M=4.28)$. Specifically, it is observed that the highest valued item, and therefore that one which showed more positive attitudes by teachers, is "I believe that accessing the Internet favours the interconnection between the scientific community and the updating of knowledge", obtaining very similar values in both genders, although slightly higher in the male $(\mathrm{M}=4.52)$. The item with the lowest evaluation by the teaching staff, although the item continues to maintain satisfactory and positive attitudes, is "I think that ICT allows me to disseminate the results of my research more quickly", where we can observe the importance of the teaching staff for communicating and sharing the articles and books published with other authors in the scientific community.

Table 5. Descriptive results of factor 3 comparing by gender

\begin{tabular}{|c|c|c|c|c|}
\hline \multirow[t]{2}{*}{ Item } & \multicolumn{2}{|c|}{ Female } & \multicolumn{2}{|l|}{ Male } \\
\hline & $\bar{x}$ & Sd. & $\bar{x}$ & Sd. \\
\hline $\begin{array}{l}\text { I believe that access to the Internet favours the interconnection between the } \\
\text { scientific community and the updating of knowledge }\end{array}$ & 4.49 & 0.75 & 4.52 & 0.75 \\
\hline $\begin{array}{l}\text { I believe that access to the Internet gives me the opportunity to learn about new } \\
\text { resources that facilitate my work as a researcher }\end{array}$ & 4.32 & 0.87 & 4.37 & 0.84 \\
\hline I believe that the use of data processing software in my research work is important & 4.24 & 0.99 & 4.30 & 0.99 \\
\hline I believe that ICT allows me to disseminate the results of my research more quickly & 4.07 & 1.04 & 4.10 & 1.04 \\
\hline Total factor 3 & 4.28 & 0.67 & 4.32 & 0.67 \\
\hline
\end{tabular}

In the normality test, the Kolmogorov-Smirnov statistician rejected the assumption of normality $(\mathrm{KS}=0.149$; sig. $=0.001)$. No significant differences were found in affective 
attitudes towards ICT research between both genders ( $U=86939,500 ; Z=-1,088$; sig. > 0.05), so the null hypothesis was accepted.

Global attitudes towards technology for teaching and research

Figure 1 shows the average obtained in the global attitude towards technology for teaching and research for both genders. It can be seen that male teachers perceive having a slightly more positive and superior attitude $(M=3.91)$ than female teachers $(M=3.79)$. The KolmogorovSmirnov test rejected the assumption of normality $(\mathrm{KS}=0.036$; sig. $=0.012)$. Significant differences were found in overall attitudes towards ICT between both genders ( $U=73716,000$; $Z=-3,314$; ff. $<0.05)$, so the null hypothesis was rejected. The size of the effect found was large $(\eta 2=0.232)$.

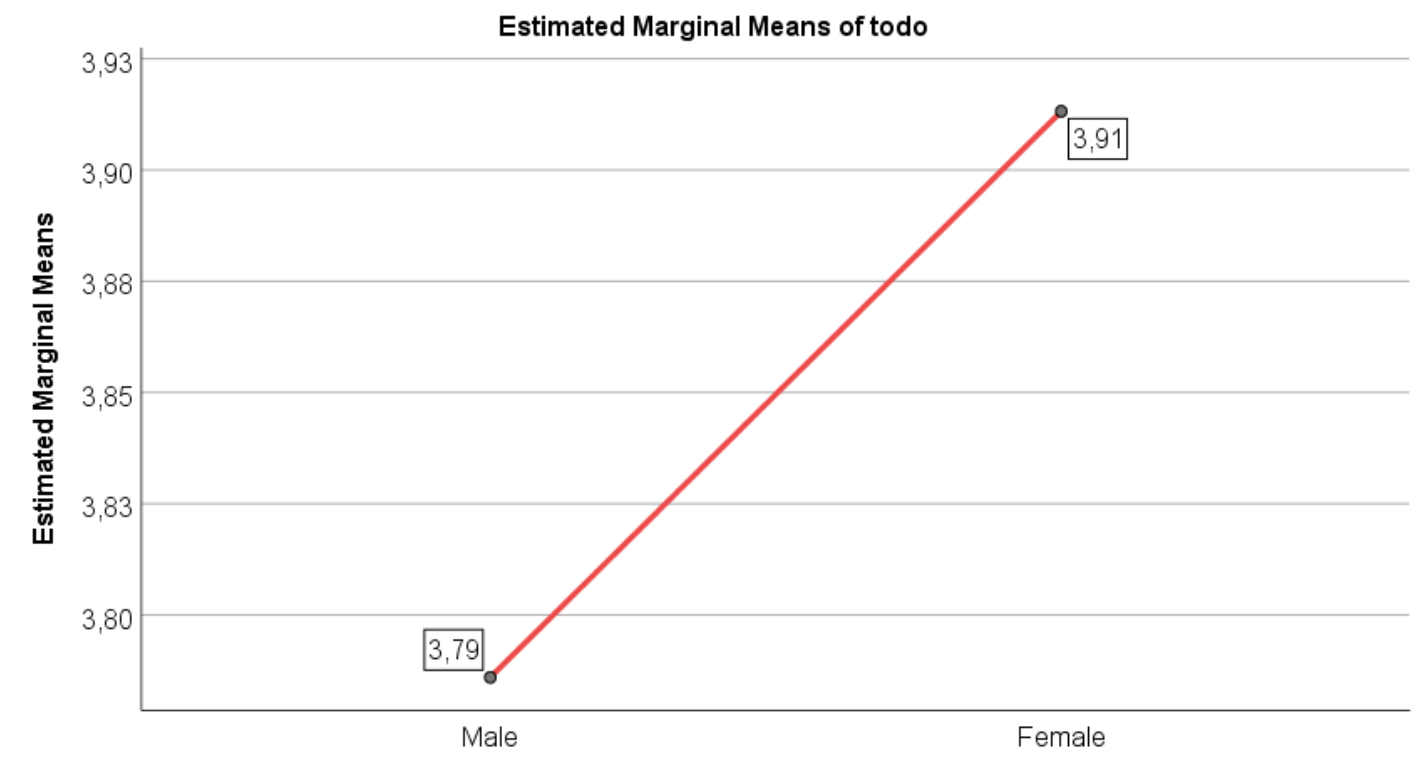

Figure 1. Global attitude towards ICT as a function of gender

\section{Conclusions}

The teacher is the key element in any process of pedagogical innovation. The success of any change process in the classroom depends largely on the attitude with which teachers approach it (Hargreaves and Shirley, 2012). The implementation of educational technology at university level is urgent (Cabero and Ruiz-Palmero, 2018). The study that we present allows us to affirm that, in general terms, Spanish university teachers have a positive attitude towards ICT. Despite the fact that small differences have been found according to gender, we can affirm that men and women present very similar levels of acceptance in comparative terms. This is common other works (Herrada et al., 2018; Sánchez-Rivas et al., 2016) have concluded that the digital gender gap does not affect the attitudes of teachers.

Considering the different areas of our study, we can draw conclusions regarding the two main activities of university teachers in Spain: teaching and research. 


\section{$3^{\text {rd }}$ International conference on Advanced Research in Education, Teaching \& Learning}

With respect to teaching, the answers provided by the teaching staff show that ICT is perceived as a valuable educational resource. Most of the teachers incorporate it in their classes on a regular basis and consider it necessary to update their knowledge about digital tools. Moreover, they understand that the incorporation of ICT is not an innovation process associated with subjects related to computing or communication; they understand it as a transversal process that links all subjects equally. This leads us to conclude that Spanish university teachers understand educational technology as a means, and not as an end in itself, in relation to the performance of their teaching duties.

Teaching planning is perhaps one of the most complex aspects of teaching work. Bozu and Manolescu (2010) note that university faculty recognize training needs around teaching planning. In many cases, it is more of a reflexive process than a technical one. We associate with this circumstance the fact that teachers place little value on the importance of ICT in the planning of their classes.

In relation to their role as researchers, university teachers greatly appreciate the support that the use of software for data processing and statistical inference provides. This type of resource greatly facilitates the research process, which explains the positive attitude towards its use.

However, in the opposite sense, faculty understand that the dissemination of their articles and reports in social networks is an added workload, which many scientific publications and events impose in order to expand their impact. This reality corresponds to the low attitudinal levels detected in relation to the updating of academic profiles on the Internet and the dissemination of research results on social networks.

In short, Spanish university teachers have a positive attitude towards the incorporation of ICT in teaching and research. This puts the university in a good position to face processes of methodological renewal that have educational technology as a cross-cutting theme and a mediator of innovation.

As can be seen from the work of Salazar and Álvarez-Gil (2020), innovation and creativity applied to teaching play a fundamental role in aspects such as student satisfaction or the improvement of dropout rates from degrees. The analysis of the relationship between the attitude of the teaching staff and these two variables constitutes an interesting line for future research.

\section{References}

Abdullah, Z. D., Ziden, B. A. and Chi Aman, R. (2015). Students' Attitudes towards Information Technology and the Relationship with Their Academic Achievement. Contemporary Educational Technology, 6(4), 338-354.

Alvarado, L.E., Aragón, R.R. and Bretones, F.D. (2020). Teachers's Attitudes Towards the Introduction of ICT in Ecuadorian Public Schools. TechTrends, 64(3), 498-505. https://doi.org/10.1007/s11528-020-00483-7 
Ankiewicz, P. (2019). Perceptions and attitudes of pupils toward technology: In search of a rigorous theoretical framework. Int. J. Technol Des. Educ., 29, 37-56. https://doi.org/10.1007/s10798-017-9434-z

Arango, D.A.G., Fernández, J.E.V., Rojas, Ó.A.C., Gutiérrez, C.A.E., Villa, C.F.H. and Grisales, M.A.B. (2020). Digital competence in university teachers: Evaluation of relation between attitude, training and digital literacy in the use of ict in educational environments. RISTI (RevistaIberica de Sistemas e Tecnologias de Informacao), E29, 538-552.

Bozu, Z. and Manolescu, M. (2010). El Espacio Europeo de Educación Superior y el profesorado universitario novel. Bordón. Revista de Pedagogía, 62(4), 51-63.

Cabero, J. and Ruiz-Palmero, J. (2018). Las Tecnologías de la Información y Comunicación para la inclusión: reformulando la brecha digital. IJERI: International journal of Educational Research and Innovation, 9, 16-30.

Cai, Z., Fan, X. and Du, J. (2017). Gender and attitudes toward technology use: A metaanalysis. Computers \& Education, 105, 1-13. https://doi.org/10.1016/j.compedu.2016.11.003

Casillas, S., Cabezas, M. y García, F.J. (2020). Digital competence of early childhood education teachers: attitude, knowledge and use of ICT. European Journal of Teacher Education, 43(2), 210-223. https://doi.org/10.1080/02619768.2019.1681393

Elliot, K. and Wilmes, D. (2013). Cognitive attitudes and values in science. Philosophy of science, 80(5), 807-817. https://doi.org/10.1086/673719

Fernández-Batanero, J.M. and Torres-González, J.A. (2015). Teacher attitudes and best practices with ICT faculty Adult Continuing Education in Andalusia. Revista Complutense de Educación, 26(special issue), 33-49.

Gómez-García, M., Soto-Varela, R., Morón-Marchena, J.A. and Pino-Espejo, M.J. (2020). Using mobile devices for educational purposes in compulsory Secondary Education to improve student's learning achievements. Sustainability, 12(9), 3724. https://doi.org/10.3390/su12093724

González-Sanmamed, M., Sangrà, A. and Muñoz-Carril, P.-C. (2017). We can, we know how. But do we want to? Teaching attitudes towards ICT based on the level of technology integration in schools. Technology, Pedagogy and Education, 26(5), 633-647. https://doi.org/10.1080/1475939X.2017.1313775

Guillén-Gámez, F.D. and Mayorga-Fernández, M.J. (2020a). Quantitative-comparative research on digital competence in students, graduates and professors of faculty education: an analysis with ANOVA. Education and Information Technologies, 25, 4517-4174. https://doi.org/10.1007/s10639-020-10160-0

Guillén-Gámez, F.D. and Mayorga-Fernández, M.J. (2020b). Identification of variables that predict teachers' attitudes toward ict in higher education for teaching and research: A study with regression. Sustainability, 12(4), 1312. https://doi.org/10.3390/su12041312

Guillén-Gámez, F. D., Álvarez-García, F. J. and Rodríguez, I. M. (2018). Digital tablets in the music classroom: A study about the academic performance of students in the BYOD context. Journal of Music, Technology \& Education, 11(2), 171-182. https://doi.org/10.1386/jmte.11.2.171_1

Hargreaves, A. and Shirley, D. (2012). La cuarta vía. El prometedor futuro del cambio educativo. Octaedro. 


\section{$3^{\text {rd }}$ International conference on Advanced Research in Education, Teaching \& Learning}

Herrada, R., Montes, R. and Ballarín, B. (2018). Rastreando marcas de género en la formación on-line. In J.B. Martínez and E. Fernández (Coords.), Ecologías del aprendizaje. Educación expandida en contextos múltiples (pp. 129-151). Morata.

Judi, H. M., Mohamed, H., and Noor, S. F. M. (2016). Perceived attitude of teachers in rural areas towards information and communication technology. Social Sciences (Pakistan), 11(23), 5590-5596. https://doi.org/10.3923/sscience.2016.5590.5596

Kumar, P. G. and Ratnakar, R. (2016). A scale to measure farmers' attitude towards ICT-based extension services. Indian Research Journal of Extension Education, 11(21), 109-112.

Maio, G. R., Haddock, G. and Verplanken, B. (2018). The psychology of attitudes and attitude change. Sage Publications Limited.

Mirete, A.B., Maquilón, J.J., Mirete, L. and Rodríguez, R.A. (2020). Digital competence and university teachers' conceptions about teaching. A structural causal model. Sustainability, 12(12), 4842. https://doi.org/ 10.3390/SU12124842

Olafare, F. O., Adeyanju, L. O. and Fakorede, S. O. A. (2018). Colleges of Education Lecturers Attitude Towards the Use of Information and Communication Technology in Nigeria. MOJES: Malaysian Online Journal of Educational Sciences, 5(4), 1-12.

Onasanya, S. A., Shehu, R. A., Oduwaiye, R. O. and Shehu, L. A. (2010). Higher institutions lecturers' attitude towards integration of ICT into teaching and research in Nigeria. Research Journal of Information Technology, 2(1), 1-10. https://doi.org/10.3923/rjit.2010.1.10

Pacheco, F., Villacis, C. and Álvarez, P. (2015). ICT's as a tool in the teaching-learning process to improve academic achievement. Revista Ciencias Pedagógicas e Innovación, 3(1), 56-68.

Prasojo, L.D., Mukminin, A., Habibi, A., Henra, R. and Iqnori, D. (2019). Building Quality Education through Integrating ICT in Schools: Teachers' Attitudes, Perception, and Barriers. Quality - Access to success, 20(172), 45-50.

Romero-Martínez, S. J., Guillén-Gámez, F. D., Ordoñez-Camacho, X. G, and MayorgaFernández, M. J. (2020). Desarrollo y estructura factorial de un instrumento de actitud hacia el uso de la tecnología para la enseñanza y la investigación en docentes universitarios. Revista Tecnología, Ciencia y Educación, 16, 85-111.

Rosen, L., Carrier, L. M., Miller, A., Rokkum, J. and Ruiz, A. (2016). Sleeping with technology: cognitive, affective, and technology usage predictors of sleep problems among college students. Sleep Health, 2(1), 49-56. https://doi.org/10.1016/j.sleh.2015.11.003

Salazar, N. and Álvarez-Gil, A. (2020). El Papel de La Universidad Frente al Abandono de Estudios. Formación Pre-Universitaria Basada En Talleres de Innovación y Creatividad. Innoeduca. International Journal of Technology and Educational Innovation, 6(1), 66-72.

Sánchez-Rivas, E., Sánchez-Rodríguez, J. and Ruiz-Palmero, J. (2016). The Influence of Gender on the Incorporation of the Internet in Spanish Schools' Educational Programmes. Research in Comparative and International Education, 11(2), 165-77.

Semerci, A. and Aydin, M. K. (2018). Examining High School Teachers' Attitudes towards ICT Use in Education. International Journal of Progressive Education, 14(2), 93-105. 
Spiteri, M. and Chang, S.N. (2020). Literature Review on the Factors Affecting Primary Teachers' Use of Digital Technology. Technology, Knowledge and Learning, 25(1), 115-128. https://doi.org/10.1007/s10758-018-9376-x

Ursavas, Ö. F., Bahçekapılı, T., Camadan, F. and İslamoğlu, H. (2015). Teachers' behavioural intention to use ICT: a structural equation model approach. In Society for Information Technology \& Teacher Education International Conference (pp. 2875-2880). Association for the Advancement of Computing in Education.

Wahyuni, S. (2018). CAC Model to Evaluate Teachers ${ }^{\text {ee }}$ Attitudes towards Technology Use in Their EFL Classrooms. Language Circle: Journal of Language and Literature, 13(1), 1-8. https://doi.org/10.15294/lc.v13i1.16659

Zhang, X., Yang, Y., Zou, X., Hu, B.Y. and Ren, L. (2020). Measuring preschool children's affective attitudes toward mathematics. Early Childhood Research Quartely, 53, 413424. https://doi.org/10.1016/j.ecresq.2020.05.012 